\title{
Education for Citizenship in Primary Education of Greece: Proposals for Pedagogical Practices by Students of Education Faculties
}

\author{
Konstantinidou Zoe \\ Aristotle University of Thessaloniki, Greece \\ Kyridis Argyris (Corresponding author) \\ Aristotle University of Thessaloniki, Greece \\ Email: akiridis@ nured.auth.gr \\ Tsioumis Konstantinos \\ Aristotle University of Thessaloniki, Greece
}

Received: January 31, 2017 Accepted: February 28, 2017 Published: March 14, 2017

doi:10.5296/ijld.v7i1.10670 URL: http://dx.doi.org/10.5296/ ijld.v7i1.10670

\begin{abstract}
Preparing students for the honor and privilege of being able to assume the role of citizen is one of the main roles and aims of education, which is considered to be one of the most important institutions as far as political socialization and civic education of children is concerned. The power of a state lies with its citizens. In a democracy, everyone is responsible for what happens in the public sphere and thus, everyone must be properly prepared for and committed to the role of citizen. The question is whether the current education system is ready and able to form conscientious and active citizens. This study consists of 103 activities that were designed with civic education in mind by students of various education faculties of various universities in Greece (students of faculties of primary education $\mathrm{N}=54$, students of faculties of preschool education $\mathrm{N}=49$ ) and analyzed. The average age of the students that participated in the study was 20.3 years. The results show that students choose activities that are mainly related to environmental education and democracy and focus less on activities related with interculturalism. More advanced students (i.e. students who are closer to graduation) are usually using more measurable objectives and experiential methods. As far as
\end{abstract}


students of faculties of primary education are concerned, it was observed that prefer to implement activities related to citizenship in large classes. Students of faculties of preschool education on the other hand, seem to plan and organize more complete activities, using specific verbs.

Keywords: Citizenship education, Pedagogical practices, Lesson activities, Pedagogical objectives.

\section{Introduction}

The main characteristic of modern society is social fluidity, which can be attributed to the advancement of scientific knowledge in the field of information and communication technology, on the economy, on society and on education, among other things. (Matthaiou, 2002).

This cultural heterogeneity is composed of a set of social, political and cultural particularities, that are expressed in the diversity of language, religion and consciousness of ethnicity as well as the diversity of attitudes and values, models regarding life and living, social organization and behavior and finally the worldview regarding life and addressing existential problems (Panagidis, 2004). This is the reason why active citizens are absolutely essential. In order for a citizen to be considered active, he or she must actively participate in the events and happenings of the world in which he or she lives. He or he must also consistently exercise his or her democratic rights and fulfill the obligations generated by those rights. An active citizen must also exhibit self and mutual respect and accept diversity and the peaceful coexistence of people and nations.

The active citizen, as visualized by the members and organizations of a civil society, should be a responsible citizen who is always aware of his rights and obligations. He should also be expressing his opinion and be an active participant in his society. The active citizen is responsible for himself, he is well informed on civic matters, he should protect the environment, he should publicly assert his rights, he should always respect diversity and of course he should always be active and not passive. According to Barber, being a citizen means participating (1984:85), while Dagger adds that one can only be considered a real citizen if he plays an active and complete role in all matters concerning his community (1981:270). Warburton and his associates on the other hand, use the term active citizen to define one who is self governed and who takes full responsibility for his actions, thus making himself less dependent on the state (2003:74). So, the key to the concept of citizenship is participation and the goal is the involvement in the process and not the result itself (Glover, 2004). Consequently, the role of the citizen who belong to a State exercising control over the political authority by participating in the political dialogue on decisions that need to be made. Depending on the manner and the extent to which citizens participate in this dialogue, they can be divided into passive or active citizens. According to Canivez (1995: 170-175) citizen activity appears to be escalating between the two extremes, depending on the degree of political activity shown by each citizen. 
A person's forming of his or her political identity starts in childhood, as that person accepts the political culture of the group in which he or she belongs (Gavalos, 2005: 22-23, Terlexis,

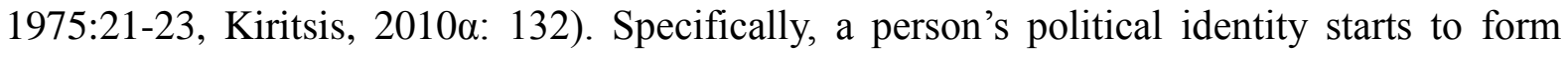
within the close circle of his family and/or wider circle of relatives and friends. The cultural environment of this circle is the first view of society that this person will get. School education is the second stage. Knowledge gained through the typical curriculum and the experiences within the school community, such as interaction with peers, participation in collective decision-making processes, learning the rules of self-discipline and learning to respect others, broaden that person's horizons, as far as world and society are concerned

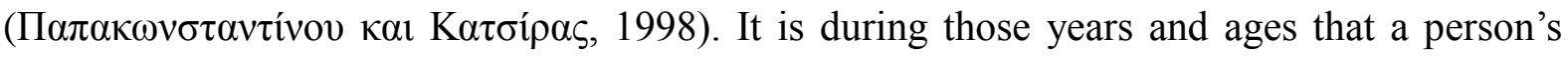
first emotional commitments to the political system are created, due to the fact that his capacity for critically processing the messages that he receives. The messages received by children are usually perceived and unquestionable and unassailable truths, and thus gain significant gravity and stability. Later in a person's life, other factors will become important, such as his career and his eventual involvement in politics (Papakonstantinou kal Katsiras, 1998). As a person grows older, he or she acquires the ability to process in a deeper level the messages that he or she receives and thus this person interprets and perceives in a different, more critical, way. The process through which people come together and embrace the political culture of the society they belong to, is known as political socialization.

A person's awareness of the fact that he is receiving political stimuli, as well as the way in which he will process those stimuli, is mainly dependant on his culture and not solely dependent on his age (Pantelidou-Maroouta, 1987: 65, Metaxas, 1976: 30-31). The goal is to achieve a harmonious co-existence of all those identities, in terms of not only the person or individual itself, but of the different groups as well. Education plays a really important in this. It is education's goal and duty to help each person develop sound and healthy citizenship, in order to ensure not only the he peaceful coexistence of different people, but also the

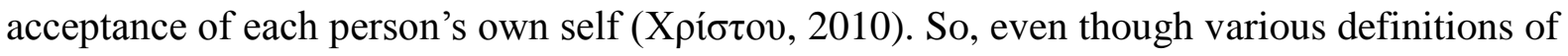
the concept of citizenship have been deemed interwoven or controversial, the fact that children's education should aim to help them become active citizens is considered common sense and is not up for debate.

The effectiveness of the learning processes is a very important factor in improving the quality of education on offer (UNESCO, 1996, World Bank, 1996, EU, 1995, Lawton et al 2000), especially from a young age (Ailwood, Brownlee, Johansson, Cobb- Moore, Walker \& Boulton, 2011). Children are particularly capable learners (students), not only on a cognitive level, but on a social and emotional level as well (Dunn 1987; Gardner 1993; Hutchby and Moran Ellis 1998; Alderson 2000; Nutbrown 2006). Mayall (2002) identifies the abilities of children to challenge, negotiate, and engage in social interaction with children and adults. Mayall is increasingly challenging and doubting traditional notions that want children to be helpless puppets in the hands of adults. The ability of very young children to actively participate actively in the world around them and to communicate their needs is accepted to be present from the time of birth (Alderson 2008). This participation should be based on perceptions of the children (Lansdown 2005). This significant focus on the early years is 
constantly drawing increasing amounts of attention from the community (Millei and Imre 2009), since we know that the classroom is a context in which children learn about moral values (Thornberg 2009).

The appropriate investments in young children are of vital importance as far as positive outcomes on a social level are concerned. The development of moral values for a tolerant and cohesive society, are among those positive outcomes on a social level (MacNaughton and Hughes 2007). The general intention of this increased attention, is to increase investment in the design of programs for children of young age (Millei and Imre, 2009), which will result in them obtaining access to quality learning (Rudd \& Macklin, 2007: 3). This is the reason why Curricula are expected to promote the skills needed for independent and lifelong learning as well as the necessary attitudes, values and skills for effective participation in modern civic society. The interest in civic education in the early years has been associated with increased investments.

Prompted by what was mentioned above, the relevant institutes are planning and implementing changes in educational systems, via new Curricula, through which they express their vision of a constantly improving future for individuals and communities as well (Le Metais, 1999), as the negative attitudes of students towards political figures seem to be reflected in negative attitudes towards institutions (Kyridis et al, 2011).

The tools used by the school for civic education consist of the curriculum and the related disciplines, but it also includes the teaching methods that the teachers adhere to. Furthermore, another very important tool is the processing of general political issues and matters during the course of the teaching process, regardless of the subject being taught, via the development of relevant discussions. In addition, the atmosphere in which those discussions take place is also very important in shaping the political identity of students, as is the active participation of students in various school activities, through which they take initiatives and gain some degree of power, elements that are part of the "hidden curriculum" (Kiritsis, 2010b: 67-68, Torney-Purta, 2004: 9).

The current image of society forces the citizen to try and redefine the very term "citizen". This is because citizens nowadays are constantly concerning themselves about their obligations and privileges. The lack of involvement of young people and the disintegration of social structures has caused intense debates and discussions regarding what were mentioned above (Kyridis, Vamvakidou and Zagkos, 2011). It seems that it is necessary for students and young people alike to be trained in order to become active citizens. This training can be achieved via the teaching of knowledge and skills that will "point them in the appropriate direction". Researches and studies regarding the evaluation of curricula, indicate that all that formal and mandatory civic education programs can be achieve, is an improvement of knowledge and not a change of attitudes (Morris et al, 2003).

Dewey emphasized that the primary goal of education should be the promotion and preservation of democracy and that each school should be a real community. He envisioned an education that would help students develop an interactive and collaborative role in society. Civic education in the sense of learning, is being taught how a community works and how it 


\section{Macrothink}

helps the common good, should be mutually reinforcing (Dewey 1916; 1938). Consequently, the school, within the context of the teaching of the subject of civic education and beyond it, should first and foremost ensure the cultivation of the appropriate morals and the right values and it should also create opportunities for students to participate in the broader community (Persianis, 2009).

\section{Method}

The goal of this study is to study the way in which the future teachers of primary education approach civic education within the school environment and through the planning of activities.

103 students (males $\mathrm{N}=9$, females $\mathrm{N}=94$ ) of Pedagogy departments in preschool education $(\mathrm{N}=49)$ and in primary education $(\mathrm{N}=54)$ of universities situated in Athens and Thessaloniki, participated in this study. The students that were selected were at least at their second semester and they had attended at least one undergraduate course related to civic education. The participants were selected both randomly and voluntarily. The average age of the participating students was twenty-three years and three months (20.3 years) (Table 1).

Table $1^{\mathrm{a}}$ : Demographic characteristics of participants

\begin{tabular}{|c|c|c|c|c|c|c|c|}
\hline \multirow{2}{*}{$\begin{array}{l}\text { FACULTY } \\
\text { Primary } \\
\text { Education }\end{array}$} & \multirow[b]{2}{*}{49} & \multicolumn{2}{|l|}{ SEX } & \multicolumn{2}{|l|}{ AGE } & \multicolumn{2}{|c|}{ SEMESTER } \\
\hline & & Male & 9 & $\begin{array}{l}18 \text { years } \\
\text { old }\end{array}$ & 3 & $2^{\text {nd }}$ & 13 \\
\hline $\begin{array}{l}\text { Preschool } \\
\text { Education }\end{array}$ & 54 & Female & 94 & $\begin{array}{l}19 \text { years } \\
\text { old }\end{array}$ & 13 & $3^{\mathrm{rd}}$ & 1 \\
\hline \multirow[t]{5}{*}{ Total } & 103 & Total & 103 & $\begin{array}{l}20 \text { years } \\
\text { old }\end{array}$ & 47 & $4^{\text {th }}$ & 33 \\
\hline & & & & $\begin{array}{l}21 \text { years } \\
\text { old }\end{array}$ & 49 & $6^{\text {th }}$ & 51 \\
\hline & & & & $\begin{array}{l}22 \text { years } \\
\text { old }\end{array}$ & 1 & $7^{\text {th }}$ & 4 \\
\hline & & & & Total & 103 & $8^{\text {th }}$ & 1 \\
\hline & & & & & & Total & 103 \\
\hline
\end{tabular}

The majority of the sample originated, was born and currently lives in either the capital of 


\section{Macrothink}

International Journal of Learning and Development

ISSN 2164-4063

Greece or its second largest city. Regarding the profession of their father most students responded with "civil servant", while as far as the profession of their mothers was concerned, most students responded with "unemployed or working at the household (housewife)"(Table $1 b)$.

Table $1^{\mathrm{b}}$ : Demographic characteristics of participants

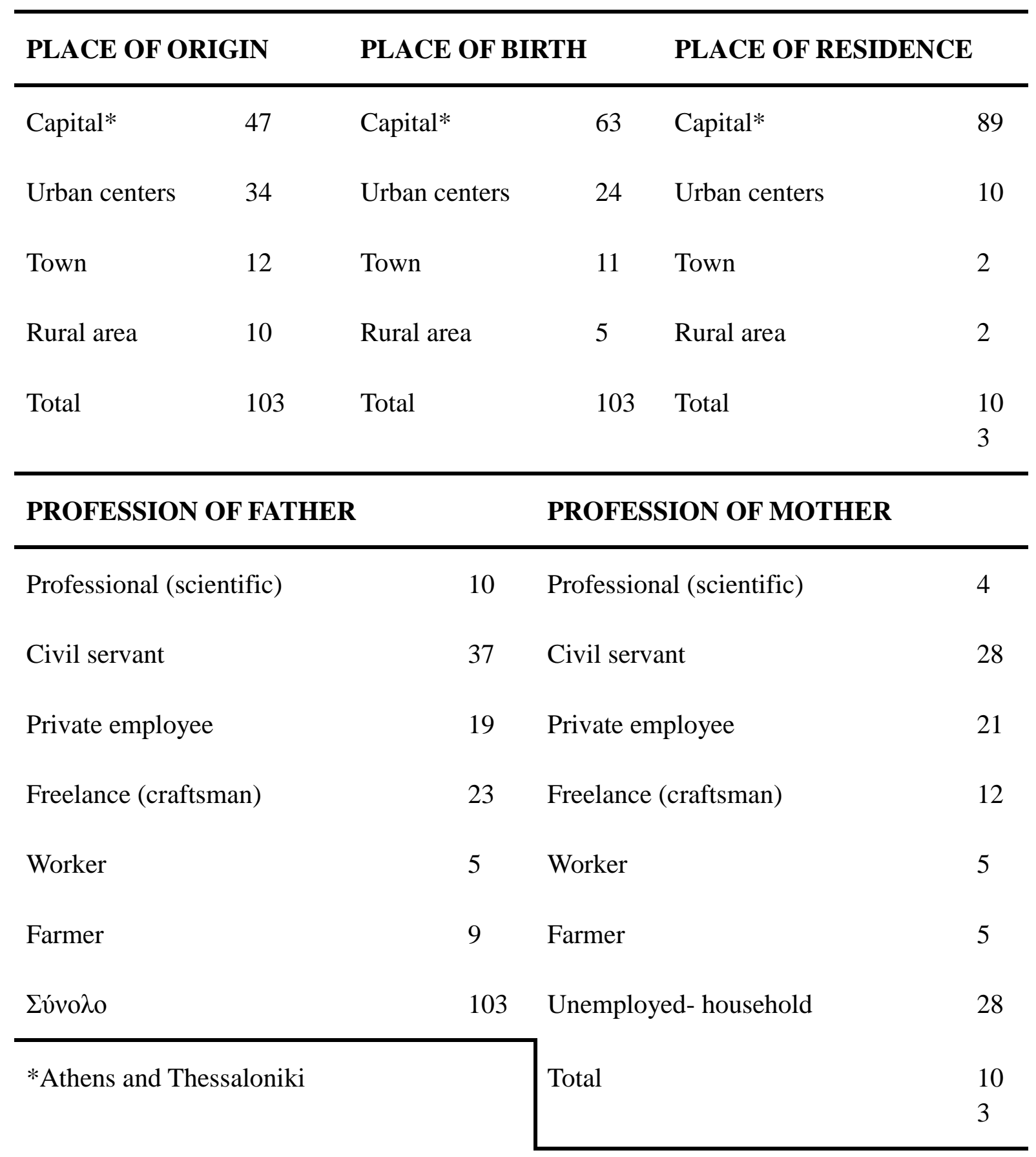




\subsection{Measuring Instruments}

A three part questionnaire, which was anonymously complete by the participants, was used for the purposes of this study. The first part of the questionnaire consisted of questions regarding demographic characteristics and data. In the second part, students were asked to answer the open question "How important do you consider civic education through the school system to be, and why?" Finally, in the third part, the students were asked to develop one civic education activity.

\subsection{Measurement Procedures}

The questionnaire was given to the participants without offering them any additional explanation and clarification. The students were selected on the term that they had become familiar with the design of educational and training activities, through their undergraduate studies. The questionnaires were complete in university classrooms and lecture halls. There was also a thirty minute time limit in the completion process. Both those factors served to ensure the optimal conditions for the participants to concentrate, think, prepare and the answer the questions on their questionnaires.

\section{Results}

The data collected was divided into two categories. The first category (E1) encompasses the suggestions that the students made through their answers in the open question "How important do you consider civic education through the school system to be? Justify your answer". The second category (E2) encompasses the design of an activity on the subject of citizenship: "Develop a civic education activity".

The content of these references was analyzed and classified into eight basic categories. Most of these references emphasize the important and vital role of civic education in modern education. Furthermore, the references also make note of the unfortunate fact that, owing to the focus on student's grades that permeates the modern education and school system, modern civic education through the school system is inadequate as far as the actual needs of future citizens are concerned. The socialization of children, the cultivation of critical thinking and the development of active citizens with rights and obligations, have also been mentioned very frequently in the references. Furthermore the importance of civic education not only in the formation of citizens with a personality of their own and a sense of responsibility, but in the formation of citizens who will not delinquent behaviors, was also highlighted (Table 2). 
Table 2: Reference Category E1

\section{PLACE OF ORIGIN}

\section{N STATEMENTS}

Very important through the 72 It is one of the most important school system goals that should be set by the

It forms the personality of 34 Young people and children form future citizens proper personalities through civil

It forms proper citizens

25 Students learn to participate in public (political) life as proper

It cultivates a feeling of 21 Students can become socially

responsibility responsible through civic

It promotes (cultivates) active 63 Every member of a society should participation take action and participate in

Democracy - Rights $-37 \begin{aligned} & \text { Through civic education students } \\ & \text { realize the fact that they have }\end{aligned}$
Obligations

Socialization 48 It prepares children for their integration in society

It cultivates and promotes 38 The main goal of education is to critical thinking form citizens capable of critical

Total 33

The relationships between the factors and the references of the students did not appear to bear statistically significant differences, which suggest that civic education is equally important to all future teachers, regardless of their University department, age, semester, place of origin and profession of parents. 368 references were produced through the qualitative analysis of the 103 activities of the E2 category. These references were then divided into four main categories: goal of the activity, development of the activity, completeness of the activity (i.e. how complete was the activity), trigger and extension of the activity. These four categories were then divided into various subcategories.

The references were then divided into two age groups, the first group encompassed references concerning children of preschool age (children of the age of 5), which derived from students 
of faculties of preschool education $(n=184)$. The second group encompassed children of school age (children of ages 6-12), which derived from students of faculties of primary education $(n=184)$. regarding this age group, it seems that most students prefer to design and plan civic education activities for children attending the last two grades of primary school (students of ages 11-2), fewer prefer to do so for students attending the two middle grades (students of ages 8-10) and much fewer prefer to plan activities for students attending the two first grades of primary school (students of ages 6-7). Overall, the students who prefer to carry out civic education activities in culturally homogenous (typical) classes outnumber those who prefer to carry out such activities in multicultural classes by two to one (Table $3 a$ ).

Table $3^{\mathrm{a}}$ : Characteristic of statements E2

\begin{tabular}{|c|c|c|c|c|c|c|}
\hline \multicolumn{2}{|c|}{ CHILDREN'S AGE } & \multicolumn{3}{|c|}{ SCHOOL CLASS* } & \multirow{2}{*}{$\begin{array}{l}\text { TYPE OF } \\
\text { CLASS } \\
\text { Typical }\end{array}$} & \multirow{2}{*}{$\begin{array}{r}\text { SCHOOL } \\
234\end{array}$} \\
\hline 5 years old & 184 & $\begin{array}{l}\text { Preschool } \\
\text { old) }\end{array}$ & (5-6 years & 184 & & \\
\hline 6 years old & 4 & $\begin{array}{l}\text { Grade } 1 \\
\text { old) }\end{array}$ & (6-7 years & 4 & Multicultural & 134 \\
\hline 7 years old & 5 & $\begin{array}{l}\text { Grade } 2 \\
\text { old) }\end{array}$ & (7-8 years & 10 & Total & 368 \\
\hline 8 years old & 20 & $\begin{array}{l}\text { Grade } 3 \\
\text { old) }\end{array}$ & (8-9 years & 10 & & \\
\hline 9 years old & 28 & $\begin{array}{l}\text { Grade } 4 \\
\text { old) }\end{array}$ & (9-10 years & 37 & & \\
\hline 10 years old & 23 & $\begin{array}{l}\text { Grade } \mathbf{5} \\
\text { years old) }\end{array}$ & (10-11 & 49 & & \\
\hline 11 years old & 35 & $\begin{array}{l}\text { Grade } \mathbf{6} \\
\text { years old) }\end{array}$ & $(11-12$ & 74 & & \\
\hline 12 years old & 69 & Total & & 368 & & \\
\hline
\end{tabular}

Total 368

Regarding the category "objective", in the subcategory "objective-verb", which addresses the clarity of the verb used to describe the goal of the activity, it seems to that the number of references that used a non-measurable verb, is equal to the number of those that used a 


\section{Macrothink}

International Journal of Learning and Development

ISSN 2164-4063

2017, Vol. 7, No. 1

measurable verb. On the other hand, as far as the content of the objective is concerned, it seems that most of the objectives are related to democracy and the environment. The objectives related to interculturalism are much fewer.

The majority of references seem to favor the use experiential activities, such as visits to places of social contribution or places related to the study and the protection of the environment, as well as actions and activities within and without the school environment (e.g. reforestation, recycling, elections) as stimulus (trigger) for the introduction of civic education activities. A significantly smaller percentage of references favor the use audio-visual material, stories, fairy tales or drama for the same purpose (Table $3 b$ ).

Table $3^{\mathrm{b}}$. Characteristic of statements E2 (Aim - Trigger)

\begin{tabular}{|c|c|c|c|c|c|}
\hline \multicolumn{4}{|c|}{ ACTIVITY GOAL } & \multicolumn{2}{|l|}{ Trigger } \\
\hline GOAL verb & & GOAL content & & Without & 6 \\
\hline Non measurable & 54 & Environment & 45 & Audiovisual material & 19 \\
\hline Measurable & 58 & Democracy & 66 & Fairy tale & 17 \\
\hline \multirow[t]{4}{*}{ Total } & 36 & Interculturalism & 27 & School visit & 23 \\
\hline & & Total & 368 & School action & 27 \\
\hline & & & & Dramatization & 11 \\
\hline & & & & Total & 103 \\
\hline
\end{tabular}

Regarding the category "activity", it seems that most references contain activities that focus on the environment and democracy, while a significant percentage of them also contain intercultural education activities. The content of these activities mostly involves actions like creating posters or building objects using recyclable materials, dramatization of stories and propositions, planting trees and participating in reforestation projects. It relies more on observation activities and "brainstorming" type of discussions and less on activities that involve teamwork, and decision making or ask of the students to take up certain responsibilities. Also of note is the fact that most students used specific verbs (to discuss, experience, decide, arrange, assist, engage, express, form, interact), while the percentage of students that used general verbs (understand, know, come in contact with, become aware, cultivate) was significantly smaller (Table $3 c$ ). 
Table $3^{\mathrm{c}}$. Characteristic of statements E2 (Description of activity)

\section{Description of activity}

\begin{tabular}{|c|c|c|c|c|c|}
\hline ACTIVITY & & \multirow{2}{*}{\multicolumn{2}{|c|}{$\begin{array}{l}\text { ACTIVITY } \\
\text { CONTENT }\end{array}$}} & \multicolumn{2}{|c|}{ ACTIVITY } \\
\hline ISSUE & & & & VERB & \\
\hline Environment & 109 & Observation & 85 & Grand & 32 \\
\hline Democracy & 91 & Cooperation & 63 & Special & 132 \\
\hline Interculturalism & 60 & $\begin{array}{l}\text { Decision } \\
\text { making/Responsibilit } \\
\text { y taking }\end{array}$ & 59 & Total & 192 \\
\hline \multirow[t]{3}{*}{ Total } & 260 & $\begin{array}{l}\text { School action (arts } \\
\text { and crafts, } \\
\text { dramatization, } \\
\text { planting of trees etc) }\end{array}$ & 123 & & \\
\hline & & Discussion & 71 & & \\
\hline & & Total & 368 & & \\
\hline
\end{tabular}

The majority of activities included visual extensions (eg the creation of a poster, a collage or a brochure) while the percentage of activities involving a visit or promotion of information and decisions made by students in environment within and without the school environment, was much smaller. Also worthy of mention is the fact that 33 of the activities had no extension, while 144 were found significantly lacking in terms structure and design (Table $3 d)$. 
Table $3^{\text {c }}$. Characteristic of statements E2 (Activity structure - extension)

\begin{tabular}{llll}
\hline $\begin{array}{l}\text { COMLETENENCE } \\
\text { ACTIVITY }\end{array}$ & OF & EXTENSION & \\
\hline Complete & 144 & Without & 32 \\
Incomplete & 86 & Arts and crafts & 52 \\
Total & 230 & Presentation-promotio & 13 \\
& & n & \\
\hline & & School visit & 5 \\
& & Total & 102 \\
\cline { 3 - 4 } & & &
\end{tabular}

\subsection{Correlations}

The results show that the factor "department" affects the measurability, generality and scope of the "goal" variables. This factor also affects the stimulus (trigger) used to introduce the activity, the action (which can be active or not active) promoted by the activity and completeness of the structure. More specifically, regarding the objective, it seems that both future kindergarten teachers and primary school teachers alike mostly set measurable objectives. The former use more specific objectives, something which is not reflected in their respective objectives during the development of the activity. What is also important, is the fact that the percentages of students of faculties of preschool education that plan and design complete activities, and is much larger than that of students of faculties of primary education.

The factor "age" of the students seems to only affect the completeness of the structure of the activity. This seems to happen because younger students mainly plan incomplete activities, but it seems that the activities that they design become more complete as they grow older and advance through the years and semesters of their departments.

The factor "semester" of studies on the other hand seems to affect the trigger used to introduce the activity and the subject matter of said activity. Specifically, students in early semesters seem to use the reading of a fairy tale as a springboard for their activities, while students of later semesters prefer to use actions and audiovisual material. Correspondingly students of earlier semesters choose the theme of "democracy" for civic education, while students of later semesters prefer choosing environmental issues over issues of intercultural nature, as far as the theme of their activities is concerned. 


\section{Al Macrothink}

International Journal of Learning and Development

ISSN 2164-4063

2017, Vol. 7, No. 1

Through the analysis the effects of the factor "origin of students", it was observed that the place of residence affects not only the content chosen by the students for their activities that they will develop, but their completeness as well. This means that out of the activities that were analyzed, the ones that further promote cooperation were the ones designed and planned by students living in urban areas. Discussion on the other hand seems to be favored by students residing in the capital of Greece and its second largest city. On the contrary, actions that involve building, drama, growing plants, etc. appear to be favored by all students, regardless of their place of residence.

The profession of the father of the students seems to affect the use of a grand or a special verb in the design and planning of activities. Students whose fathers worked in the private or the public sector or were freelance worker appear to mainly choose and use objectives with specific content (children to discuss, experience, decide, arrange, assist, engage, express, form, interact). On the other hand, regarding students whose fathers were workers or manual laborers, the number of students that used general verbs is equal to the number of those that used special verbs.

Regarding the profession of the mother, it was observed that it affects more variables, such as the suitability of the verb used to make the objective, the theme and the content of the activity as well as its completeness. Consequently, regarding the theme of "action" and the students that favor it, the number of students whose mothers are freelance worker (scientists) working in either the public or the private sector, are the highest. Regarding the theme of "collaboration" on the other hand, it seems to be favored mainly by students whose mothers are farmers or work in the field of agriculture in general. Things are pretty similar, regarding the theme of "activity", since students whose work in either the public or the private sector or are freelance worker, mainly choose activities that focus on the theme of democracy and cultural diversity, while all students regardless of the profession of their mothers, chose activities related to the environment.

Finally, regarding the grade for which the activities were designed and planned, it was observed that the majority of the activities designed for children attending kindergarten were complete. On the other hand, most activities designed and planned for children attending primary school were found to be lacking in terms of structure and design, regardless of the grade for which they were designed. The only exception to this, were the activities designed for students of the second grade. It also seems that the type of class also affects the choices made by the students participating in the study regarding the verbs accompanying the goal of the activities. Specifically, it was observed that more specific and clearer objectives were selected for typical classes, while more vague objectives were set in multicultural classes (Table 4). 
Table 4: Crosstabs

\begin{tabular}{lll}
\hline FACULTY & F & Sig. \\
\hline Aim - verb (appropriateness) & 7.903 & .006 \\
Aim - verb & 20.291 & .000 \\
Trigger & 4.596 & .034 \\
Activity - verb & 13.336 & .000 \\
Completeness of activity & 32.866 & .000 \\
\hline AGE & 3.070 & .029 \\
\hline Completeness of activity & & \\
\hline SEMESTER & & .026 \\
\hline Trigger & & .001 \\
\hline Activity (issue) & 4.282 & \\
\hline
\end{tabular}

\section{PLACE OF RESIDENCE}

\begin{tabular}{lcc}
\hline Activity (content) & 7.563 & .000 \\
Completeness of activity & 3.137 & .026 \\
\hline PROFESSOR (FATHER) & 3.219 & .008 \\
\hline Activity - verb & & \\
\hline
\end{tabular}

\section{PROFESSION (MOTHER)}

Aim - verb (appropriateness)

Activity (issue)

Activity (content) 
Completeness of activity

SCHOOL CLASS

Completeness of activity

TYPE OF SCHOOL CLASS

\section{Discussion}

Democracy, respect for human rights, tolerance, solidarity and participation, are the main values included in education for citizenship. Furthermore, several countries also include respect for nature in these values. The objective of civic education is to politically educate students and to help them develop the behaviors and values needed to become responsible citizens and to encourage active participation in both their school life and community life. That is why a very large part of the students that participated in this study emphasize the importance and necessity of civic education in modern education and the need for relevant and substantive actions that will transcend the focus on student's grades that defines modern education.

The fact that the efficiency of the learning processes is an important factor in improving the quality of education (UNESCO, 1996, World Bank, 1996, EU, 1995, Lawton et al 2000), has been highlighted several times. The method used in teaching the subject of civic education should definitely belong to the category of social methods (individual and group projects, discussions, etc.) and it should be based on interaction (Damanakis, 1990:143-152). This seems to be promoted by students of both faculties and mainly by students coming from the capital of Greece and its second largest city. This is a sign of hope regarding the methods that those students seem to prefer, since there are many and important ways in which teaching process of the subject of civic education can be improved, such as better integration of community service, classroom discussions, readings and field studies (Ehrlich, 1999).

Important is also the fact that these students, through their choices, try not only to recall personal experiences of students, but to create new ones as well, is also very important. While examining the teaching of citizenship in primary schools, Adams (2005), notes that practical involvement and awareness of issues affecting / involving people, are the key to learning to be a citizen. As far as children are concerned however, citizenship depends on their relationships with adults, especially during their early years. The reason for that is the fact that a child's right of participation and the extent of the participation of children in social life are still dependent on the perceptions of adults regarding the ability of children to participate (Ailwood, Brownlee, Johansson, Cobb-Moore, Walker \& Boulton, 2011). Here is where we must note a confusion that mainly concerns preschool children: they seem to be viewed as both participants and persons in need of protection. The reason for that is the fact that even 
though the abilities of young children are constantly evolving and require the support and protection of adults (Lansdown 2005), they also need reinforcement through stimuli and opportunities for independence and personal will.

Issues concerning the fundamentals of civic education should be present and disseminated across the curriculum. This is also supported by the interdisciplinary approach to knowledge. This is evident in the plans made the students, since they use various cognitive areas to approach the concept of civic education. The students however seem to be more focused on bringing the children into contact with the environment. Protection of the environment, reforestation, recycling and cleanliness seems to be the main focus of students when it comes to introducing the basic concepts of citizenship. According to Niens and Reilly (2012), the teaching of environment issues and matters has the potential to be used as a starting point for the development of a crucial perspective within the wider, global civic education: students are concerned about global inequality, and thus they are incentivized to act in order to improve the living conditions of people around the world.

According to current trends (Chatzigeorgiou, 2001) each curriculum should be studied and evaluated. The main focus of this study and evaluation should be on whether the curriculum achieves the objectives that it set and especially those which are directly related to the assessment of the student's performance. More specifically, the main focus should be on objectives related to the acquisition and understanding of the basic concepts present in the content by the students, to the promotion of the students ability to manage the acquired knowledge and to the development of the overall ability of students to use the scientific method in order to find solutions to problems. Curricula should also be flexible in order to account for the specific conditions and parameters of each school, since those can significantly affect the acquisition of knowledge by the students, as well as the formation of their attitudes. Such parameters include the ethnic composition of the student population and the degree of autonomy of the school, regarding the activities and objectives that it can promote. This may be the reason why the references concerning typical classes is double that of the references concerning multicultural classes. Also, most of the references concerning typical classes contain special objectives, while most of the references concerning multicultural classes contain general and vague objectives. Ross (2007) emphasizes the value of citizenship and the consequent assertion of individual rights not only at national but also at European level. He also compares the identity of the citizen in states of the past with the identity of the citizen in modern states and he concludes than in the past the identity of them was defined by the state to which they belonged, while nowadays there are many elements that define citizenship and they also determine multiple identities. Because of this, Ross considers the European Union's policy to encourage its citizens to accept multiple identities to be correct, because it makes it easier for them to influence each other.

The methods of observation and brainstorming seem to dominate the preferences of the students. On the other hand students who reside in urban areas seem to use the tools of cooperation and joint decision making when planning and designing their activities, but not to the maximum extent appropriate. Through a teaching process that focuses on the cooperation between groups or teams, the teacher provides the potential of the students for interaction, 
regardless of the category to which they belong. This way of teaching also creates, conscientiously and systematically, a social context of acceptance, encouragement and collaboration, regardless of school knowledge, school performance, gender, social and cultural background (Touplikioti, 2007). By analyzing the plans and designs made by the students who participated in this study, one gets the impression that the students did not take advantage of those capabilities. This was more evident on references regarding classes if younger children. The same appears to have also occurred in programs organized by the European Union (Youth for Europe and Socrates). In these programs, the projects designed by the teachers for younger children, seemed to put less emphasis on democratic participation and involvement in the development and implementation of the project, than those that were designed for older children.

Of great importance is also the fact that students use activities involving other classes or even the entire school, as well as activities that involve the cooperation of the school with social and political bodies. This fact is important because the concept of political socialization is very broad and it includes not only conscious processes (such as direct transmission of knowledge), but unconscious as well. Through these processes new ideas, beliefs and values such as freedom, social justice, empowerment and meaningful political participation are communicated and transmitted to new generations. Moreover, these processes do not only concern the school as an institution of political socialization, but it also concerns other agencies and bodies, institutions, symbols and models, which are related in either a direct or indirect manner to the state and by extension to politics. This means that the general political education is achieved not only through direct and deliberate teaching, but also through the interaction of people with all the socio-political elements mentioned above and through the experiences gained by developing relationships with other people in their environment. Specifically, people develop social relations both within and without the context of politics, which means that they experience various daily experiences within their familial and social environment, which provide them with a wealth of information regarding political processes and procedures, and in particular on those processed and procedures related to the state apparatus (Gavalos, 2005).

Finally, another important finding of the study is the observation that students of faculties of preschool education designed activities that were more complete than those designed by students of faculties of primary education. This may be due to the fact that the curriculum regarding preschool education is very flexible and it allows for great amounts of freedom regarding the focus on themes and topics that may arise within and without the school environment (Karadimou, Tsioumis and Kyridis, 2014). The curriculum of primary education on the other hand, allows a very small degree of freedom and improvisation as far covering the syllabus and fulfilling teacher trying to cover the cognitive demands are concerned. As a result, the curriculum tends to impose very strict and inflexible timeframes regarding teaching contents, which restrict the teacher and force him or her to adhere to very specific frames regarding syllabus, time and activities. This fact complicates the design activities about citizenship because every student and teacher is faced with the experiences of local communities that may not have been included in the curriculum (Apple, 2004; Kossivaki, 
1998). In order for the teacher to achieve a level harmony between the cognitive subjects being taught and the needs and interests of the children, as well as the special local conditions of each community, it is sometimes necessary to move away from the official curriculum, but he or she must do so without losing track of the purpose and objectives of school. In other words, the teacher will have to accept the responsibility of his or her independence. (Mavrofiorgos, 1992)

\section{Conclusions}

School, as both a place and as an institution, is purely political in nature, since within its context and particularly through the civic education that it provides, it transfers knowledge concerning the state, the Constitution, laws and institutions. It also teaches to children the meaning of awareness, communication and justice. At the same time, it also highlights political life as a constant assertion of power through dialogue. This way school prepares future citizens for their participation in society and public life and it provides them with the right skills that will allow them to participate in public political debates, without violating the principles of freedom and equality when doing so. This shows the need for a comprehensive and systematic teaching proposal that will includes teaching objectives, teaching content and methods of knowledge transfer. The design and distribution of appropriate educational and support materials can deeply and substantially facilitate the organization and implementation of activities for both civic education and educational work in general. This is the reason why, the curricula are expected to promote the skills needed for independent and lifelong learning, as well as the necessary attitudes, values and skills for effective participation in matters of citizenship in modern society. There is also a need for properly trained teachers who will implement this teaching proposal. Academic curricula, particularly those of humanitarian and pedagogical schools, should take into account the above and integrate within their context and framework the respective guidelines for the promotion of citizenship, since it is a field characterized by constant enrichment, mutation and evolution. This subject is and will always be topical, while it also promises to greatly concern us in the future.

\section{References}

Adams, P. (2005). Citizenship: How is it different to PSHE and how can it be done? Education 3-13 33, 3:57-62.

Ailwood, J., Brownlee, J., Johansson, E., Cobb-Moore, C., Walker, S. \& Boulton-Lewis, G. (2011). Educational policy for citizenship in the early years in Australia, Journal of Education Policy, 26:5, 641-653

Alderson, P. (2000). Young children's rights. London: Jessica Kingsley

Alderson, P. (2008). When does citizenship begin? Economics and early childhood. In Children and citizenship, (Eds). Antonela, Invernizzi and Jane, Williams, 108-19. London: Sage

Apple, W.M. (2004). Ideology and curriculum, 3rd edition, New York: RoutledgeFalmer 
Barber, B. (1984). Strong Democracy. Berkeley: University of California Press

Carnivez, P. (1995). Eduquer le citoyen?, $2^{\text {nd }}$ edition, Paris:Hatier

Chatzigeorgiou, I. (2001). Know the curriculum. Athens: Atrapos (in Greek)

Christou, E. (2010). The concept of polarity and civic education. Proceedings of the 11th Conference of the Pedagogical Society of Cyprus, 66-73 (in Greek)

Dagger, Richard. 1981. Metropolis, memory and citizenship. Journal of Political science 25(4), 715-734

Dewey, J. (1916). Democracy and Education. New York: MacMillan.

Dewey, J. (1938). Experience and Education. New York: Collier Books.

Dunn, J. (1987). The beginnings of moral understanding. In Joan, Kagan and Sharon, Lamb (Eds). The emergence of morality in young children, 109-17. Chicago: University of Chicago Press Falmer

Ehrlich, T. (1999). Civic Education: Lessons Learned. Political Science and Politics, 32(2), 245-250

Givalos, Menelaos. (2005). Political Socialization and educational environment. Athens: Nisos (in Greek)

Glover, Ty. (2004). The Community Center and the social construction of Citizenship, Leisure Sciences 26:63-83

Hutchby, I. and Moran Ellis J. (1998). Children and social competence. London: Falmer

Karadimou, M., Tsioumis, K., Kyridis A. (2014). What Greek Primary School Teachers Believe about Citizenship Education? International Journal of Learning \& Development, 4(4), 81-96

Kiritsis, D. (2010b). Political socialization of young people: A review of the literature. The educational, 93-94, 61-73(in Greek)

Kossivaki, F. (1998). Criticism Communicative Teaching. Athens: Gutenberg (in Greek)

Kyridis, A., Michailidis, I., Papoutzis, L., Vamvakidou, I. (2011). Economic crisis, visual literacy and citizenship: Six cartoonists "targeting" the economic crisis. Proceedings of the 3rd South European and Mediterranean Conference on Citizenship, Identity and Culture, University of Patras, 6-8/5/2011.

Kyridis, A., Vamvakidou, I. and Zagkos, Ch. (2011). Greek university student's participation in national elections: Voting behavior and signs of political apathy and decreasing civic consciousness in the context of economic crisis in Greece. In: P. Cunningham \& N. Fretwell, (eds) Europe's Future: Citizenship in a Changing World. London: CiCe, 397 - 412.

Kyridis, A., Zagkos, Ch., Papadakis, N., Daskalaki, N. and Fotopoulos, N. (2011) Politics, Politicians, political system and Democracy in Greece: the quest of an actual reformation. 


\section{Macrothink}

International Journal of Learning and Development ISSN 2164-4063 2017, Vol. 7, No. 1

Views and beliefs of Greek university students. Proceedings of the 3rd South European and Mediterranean Conference on Citizenship, Identity and Culture, University of Patras, $6-8 / 5 / 2011$.

Lansdown, G. (2005). Can you hear me? The right of young children to participate in decisions affecting them. Working Paper 36. Bernard Van Leer Foundation, The Hague, The Netherlands

Lawton, D., Cains, R.\& Gardner, J. (2000). Education for citizenship, London: Typeset Ltd.

Le Metais, J. (1999). Values and aims in curriculum and assessment frameworks: a 16-nation review. Moon, Bob \& Patricia, Murphy (Eds) Curriculum in Context. London: Paul Chapman Publishing.

Lister, R. (2008). Unpacking children's citizenship. In A., Invernizzi and J., Williams (Eds) Children and citizenship, 9-19. London: Sage

MacNaughton, G. \& Hughes, P. (2007). Teaching Respect for Cultural Diversity in Australian Early Childhood Programs: A Challenge for Professional Learning. Journal of Early Childhood Research 5(2), 189-204

Matthaiou, D. (2002). The education of the challenges of the 21st century. Athens: Livani (in Greek)

Mayall, B. (2002). Towards a sociology for childhood. London: Routledge Falmer

Mavrogiorgos, G. (1992). Teachers and Teaching. Athens: Modern Education (in Greek)

Metaxas, A. (1976). Political Socialization. Athens: Olkos (in Greek)

Millei, Z. \& Imre, R. (2009). The problems with using the concept of 'citizenship' in early years policy. Contemporary Issues in Early Childhood, 10(3), 280-290.

Morris, Z., Slote, J.P. \& Halpern D. (2003). Compulsory citizenship for the disenfranchised: benchmarking students, schools, and social political attitudes before citizenship. The Curriculum Journal, 14, 2, 181-199

Niens, U. \& Reilly, J. (2012). Education for global citizenship in a divided society? Young people's views and experiences. Comparative Education, 48(1), 103-118

Nutbrown, Cathy. 2006. Threads of thinking: Young children learning and the role of early education. 3rd edition, London: SAGE.

Panagidis, A. (2004). The role of intercultural education. Fileleftheros (in Greek)

Panagidis, A. (2007). The imperatives of multiculturalism in contemporary citizenship. Pilitis, 102 (in Greek)

Pantelidou - Malouta, M. (1987). Political attitudes and perceptions in early adolescence: political socialization within the Greek political culture. Athens: Gutenberg (in Greek)

Ross, A. (2007). Citizenship Education and Change. In: Citizenship Multiculturalism 


\section{Macrothink \\ International Journal of Learning and Development \\ ISSN 2164-4063 \\ 2017, Vol. 7, No. 1}

Cosmopolitanism. International Conference. Contributed Papers. Cyprus, 2007, 16-22

Rudd, K. \& Macklin, J. (2007). New Directions for Early Childhood Education: universal access to early learning for 4 year olds. Australian Labor Party. http://www.alp.org.au/download/now/new_directions_in_early_childhood_education.pdf

Terlexis, P. (1975). Political socialization: The political origins of human. Athens: Gutenberg (in Greek)

Thornberg, Rt. (2009). The Moral Construction of the Good Pupil Embedded in School Rules. Education, Citizenship and Social Justice 4, 3: 245-261

Torney-Purta, J. (2004). Adolescent's political socialization in changing contexts: An international study in the spirit of Nevitt Sanford. Political Psychology, 25(3), 465-478.

Touplikioti, S. (2007). The application of the method of work plans in day school. Scientific Forum, 6 (in Greek)

UNESCO (1996). Education and the Treasure within. Paris: INE.

World Bank (1996). Human Capital for Better Lives. Washington D.C.: The World Bank.

\section{Copyright Disclaimer}

Copyright for this article is retained by the author (s), with first publication rights granted to the journal.

This is an open-access article distributed under the terms and conditions of the Creative Commons Attribution license (http://creativecommons.org/licenses/by/3.0/) . 